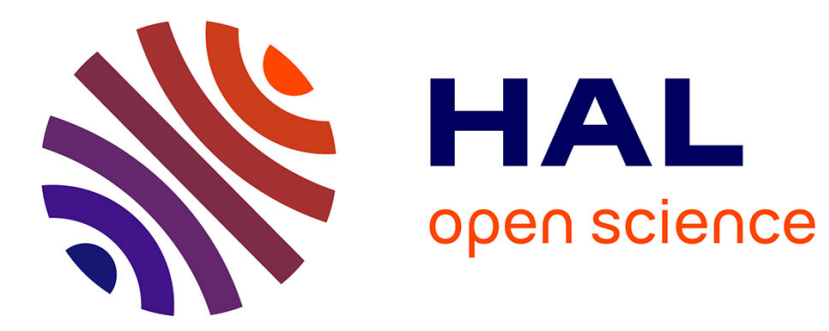

\title{
SYMPTOMS OF EXPERIMENTAL ENDOLYMPHATIC HYDROPS : POSSIBLY A POTASSIUM CONTAMINATION FROM PERILYMPH
}

K. Horner, Y. Cazals

\section{To cite this version:}

K. Horner, Y. Cazals. SYMPTOMS OF EXPERIMENTAL ENDOLYMPHATIC HYDROPS : POSSIBLY A POTASSIUM CONTAMINATION FROM PERILYMPH. Journal de Physique IV Proceedings, 1992, 02 (C1), pp.C1-257-C1-260. 10.1051/jp4:1992154 . jpa-00251225

HAL Id: jpa-00251225

https://hal.science/jpa-00251225

Submitted on 1 Jan 1992

HAL is a multi-disciplinary open access archive for the deposit and dissemination of scientific research documents, whether they are published or not. The documents may come from teaching and research institutions in France or abroad, or from public or private research centers.
L'archive ouverte pluridisciplinaire HAL, est destinée au dépôt et à la diffusion de documents scientifiques de niveau recherche, publiés ou non, émanant des établissements d'enseignement et de recherche français ou étrangers, des laboratoires publics ou privés. 


\title{
SYMPTOMS OF EXPERIMENTAL ENDOLYMPHATIC HYDROPS : POSSIBLY A POTASSIUM CONTAMINATION FROM PERILYMPH
}

\author{
K.C. HORNER and Y. CAZALS \\ Laboratoire d'Audiologie Expérimentale, Inserm Unité 229, Université de Bordeaux II, Hôpital \\ Pellegrin, Place Amélie Raba-Léon, F-33076 Bordeaux cedex, France
}

\section{ABSTRACT}

The cause(s) of Menière's disease is(are) not known but two main hypotheses have been proposed and have been widely accepted, to explain the characteristic symptoms: low frequency hearing loss, tinnitus and vertigo. It is supposed that there is an overpressure within the endolymphatic spaces accompanied by fissures in the membranes, and in particular in the Reissner's membrane, which leads to the mixing of potassium rich endolymph with perilymph. Our data do not fit well with such hypotheses and we have proposed a different mechanism. According to our hypothesis the swelling volume of endolymph displaces the Reissner's membrane towards scala vestibuli (SV) [which has a $\mathrm{K}+$ concentration of $6.4 \mathrm{mM}$ ] which forces the outfiow of perilymph through the helicotrema into scala tympani (ST) [which has a $\mathrm{K}+$ concentration of $3.4 \mathrm{mM}$ ). The relative doubling of the concentration of $K$ within the ST towards the apex of the cochlea might provoke low frequency sensitivity loss, tinnitus, and cause a local deterioration of sensory hair cells and spiral ganglion cells.

\section{RESUME}

Les causes de la maladie de Menière ne sont pas connues. II y a deux hypothèse répandues pour expliquer les symptomes associées: une perte de sensibilité pour les fréquences graves, des acouphènes, des crises de vertiges. On suppose qu'il y a une surpression dans les espaces endolymphatiques et des fissures dans les membranes et en particulier celle de Reissner et par suite il y aurait un mélange de l'endolymphe avec la périlymphe. Nos données sur le modèle ne sont pas en accord avec ces hypothèses et nous proposons une nouvelle hypothèse. Selon celle-ci il y aurait un flux de la périlymphe de la rampe vestibulaire (qui a une concentration de $\mathrm{K}+$ de $6,7 \mathrm{mM}$ ) à travers l'helicotrème vers la rampe tympanique (qui a une concentration de $\mathrm{K}+$ de 3,4 mM). L'augmentation de la concentration de potassium dans la rampe tympanique vers l'apex de la cochlée peut provoquer une perte de sensibilité pour les basses fréquences ainsi que des acouphènes et aussi une dégénérescence des cellules sensorielles et ganglionnaires.

\section{INTRODUCTION}

Post-mortem investigation of human temporal bones demonstrates the presence of hydrops in the endolymphatic spaces of some inner ears from patients who have suffered from various of inner ear disorders (Schuknecht and Gulya, 1983; Paparela, 1984). On the other hand endolymphatic hydrops is almost systematically associated with Menière's disease temporal bones (Schuknecht and Rüther, 1991). Menière's disease is an inner ear disorder characterised by the three classic symptoms of fluctuant hearing loss, vertigo 
and tinnitus. The clinical management of this disorder remains problematic primarily because the cause(s) of the disease is(are) unknown. In addition the precise effects of endolymphatic hydrops on inner ear function are unknown. The general aims of our studies are to investigate the effect of endolymphatic hydrops on the inner ear function in the guinea pig and hence to attempt to shed some light on the symptoms observed and in this way to possibly improve the management of the endolymphatic hydrops.

Endolymphatic hydrops can be induced in animals according to a number of techniques (Kimura, 1982), however the model most widely employed, and used by us, is that described first by Naito (1950). The surgical blocking of the endolymphatic dunct results in an endolymphatic hydrops throughout the vestibule and the cochlea.

The animals are chronically-implanted with a round window electrode, surgical induction of hydrops is carried out and the evolution of the inner ear pathology is followed by electrophysiological monitoring and by observation of the inner ear morphology after sacrifice at different stages. After several years of investigation a number of features particular to the hydrops model have been identified and are presented below. In addition our experimental data have led us to re-evaluate the contribution of hydrops to the observed symptoms associated with Menière's disease which is discussed.

\section{ELECTROPHYSIOLOGICAL DATA}

According to our observations the hearing dystunction, which is observed following the experimental induction of endolymphatic hydrops, can be considered to evolve progressively according to 3 well defined stages. The first two months are characterised by a selective low frequency fluctuant hearing loss (Horner and Cazals, 1987). Whilst at this stage the thresholds for the very high frequencies have not changed, those frequencies become hypersensitive to high level sounds such that the level required to induce temporary threshold shifts is considerably lower than normal (Horner, 1990). In a later phase the thresholds for the very high frequencies become elevated and it appears that the mid frequencies (around $8 \mathrm{kHz}$ for the guinea pig) are the last to become affected such that a mid-frequency (best) peak can be identified (Horner and Cazals, 1991). This type of progressive and selective evolution resembles remarkably that observed in Menière's patients where the peak audiogram,(around $2 \mathrm{kHz}$ ), was first ascribed by Paparella et al. (1982).

In an attempt to describe the possible contribution of endolymphatic pressure to the evolution of the hearing loss we have increased the hydrostatic pressure, in normal control cochleas, within the endolymphatic spaces by means of a cannula sealed within the endolymphatic duct (Horner and Cazals, 1990). Under such experimental conditions a rapid high frequency sensitivity loss was characteristically recorded. These observations led us to conclude that a hydrostatic pressure might contribute significantly to the hearing loss in a late phase of hydrops (Horner and Cazals, 1991).

\section{MORPHOLOGICAL DATA}

Earlier studies have described the loss of hair cells and spiral ganglion celis at the apex of the cochlea and the lack of correlation with the hearing loss (Aran et al. 1984; Albers et al, 1987). We, however, decribed for the first time a new outer hair cell stereocilia pathology particular to the hydropic cochleas (Horner et al. 1988, 1989, Rydmarker and Horner, 1990) which is characterised by a selective atrophy of the short and middle stereocilia on all the outer hair cells in the upper three cochlear turns. Indeed in long-standing hydrops the hair cell loss remains restricted very much to the upper cochlear turn whilst stereoclla atrophy has been identified by us, in very early hydrops, to be located primarily in the second and third cochlear turns. We have thus reached the inevitable conclusion that the low frequency hearing loss and in particular the fluctuations in the sensitivity at those frequencies are closely related to the selective atrophy of the short and middle stereocilia on the outer hair cells. Indeed more recently we have demonstrated a very close correlation both in time and tonotopy between that pathology and the low frequency fluctuant hearing loss (Rydmarker and Homer, 1991).

\section{INTERPRETATIONS}

The data from our model demonstrates different distinct phases in the development of the hearing loss such that a peak-audiogram can be identified at some stage. We believe that whilst the swelling volume of endolymph is the overall causal factor, the underlying mechanisms leading to the low frequency loss and those leading to the high frequency loss are likely to be quite different. 
As detailed above we have established that the low frequency loss is associated with stereocilia atrophy on the outer hair cells. On the other hand our experiments on pressure application in control cochleas suggested that the high frequency loss might be associated with an endocochlear pressure. A leakage of high $K_{+}(160 \mathrm{mM})$ from the endolymphatic spaces into the perilymph would be extremely toxic for hair cell function and would not allow for the rapid fluctuation of sensitivity that we have observed in the animal model. An alternative mechanism has recently been presented (Horner 1991) which fits better with our data. According to our new hypothesis the swelling volume of endolymph displaces the Reissner's membrane towards scala vestibuli (SV) $[\mathrm{K}=6.4 \mathrm{mM}$ ] which forces the outflow of perilymph through the helicotrema into scala tympani (ST) $[K=3.4 \mathrm{mM}]$. The relative doubling of the concentration of $\mathrm{K}+$ within the ST at the apex of the cochlea might provoke low frequency sensitivity loss and tinnitus. This hypothesis is the first which might account for the observed loss of sensory hair cells and spiral ganglion cells selectively at the apex of the cochiea. In addition micromechanical disturbances due to the increasing volume of endolymph might cause stretching of stereocilia inter-row cross links resulting in intermittent hair cell function and hence fluctuant sensitivity. When the bulging Reissner's membrane has extended maximally to the outer cocilear wall two phenomena might be observed the continued increase in the volume of endolymph might induce an endolymphatic pressure and secondly the drastically reduced volume of perilymph in the scala vestibuli might result in an intra-cochlear conductive loss giving rise to the feeling of fullness of the ear as is commonly reported in Menière's disease.

\section{REFERENCES}

Albers, F.W.J., Veldman, J.E. and Huizing, E.H. (1987) Early hair cell loss in experimental hydrops. Annals Otol. Rhinol. Laryngol. 96, 282-285.

Aran, J.M., Rarey, K.E. and Hawkins, J.E. (1984) Functional and morphological changes in experimental endolymphatic hydrops. Acta; Otolaryngol. 97, 547-557.

Horner, K.C. (1990) Hypersensitivity of hydropic ears, at trequencies with normal thresholds, to temporary threshold shifts. Hearing Res. 48, 281-286.

Horner, K.C. (1991) Old theme and new reflections: Hearing impairment associated with endolymphatic hydrops. Hearing Res. 52, 147-156.

Horner, K.C. and Cazals, Y. (1987) Rapidly fluctuating thresholds at the onset of experimentally induced hydrops in the guinea pig; Hearing res. 26, 319-325.

Horner, K.C. and Cazals, Y. (1990) Alterations of CAP audiogram by increased endolymphatic pressure and its relation to hydrops. Hearing Res. 45, 145-150.

Horner K.C. and Cazals, Y. (1991) Contribution of increased endolymphatic pressure to hearing loss in experimental hydrops. Annals Otol. Rhinol. Laryngol. 100, 496-502.

Horner, K.C., Cazals, Y. and Guilhaume, A. (1989) Round window cochlear microphonis and atrophy of short and middle stereocilia on outer hair cells in hydropic cochlease in guinea pigs; In: Cochlear Mechanisms (eds) J.P. Wilson and D.T. Kemp, Plenum Press.

Horner, K.C., Guilhaume, A. and Cazals, Y. (1988) Atrophy of middle and short stereocilia on outer hair cells of guinea pig cochleas with experimentally induced hydrops. Hearing res. 32, 41-48.

Kimura, R.S. (1982) Animal models of endolymphatic hydrops. Am. J. Otolaryngol. 3, 447-451.Naito, T.

(1950) Experimantal studies on Menière's disease. Jpn. J. Otol. 53, 19-20.

Paparella, M.M. (1984) Pathology of Menières disease. Annals Otol. Rhinol. Laryngol. 93, 31-35.

Paparella, M.M., Mc Dermot, J.C. and de Sousa, L.C.A. (1982) Meniere's Disease and the peak audiogram. Arch. Otolaryngol. 108, 555-559.

Rydmarker, S. and Horner, K.C. (1990) Morphological changes of hair cell stereocilia and tectorial membrane in guinea pigs with experimental hydrops. Scanning Microsopy International, 4, 705-714.

Rydmarker, S. and Horner, K.C. (1991) Atrophy of outer hair cell stereocilia and hearing loss in hydropic cochleae. Hearing Res. 53, 113-122.

Schuknecht, H.F. and Gulya, A.J. (1983) Endolymphatic hydrops: An overview and classification. Annals Otol. Rhinol. Laryngol. 92, 1-20.

Schuknecht, H.F. and Rüther, A. (1991) Blockage of the longitudinal flow in endolymphatic hydrops. Eur. Arch. Otorhinolaryngol. 248, 209-217. 

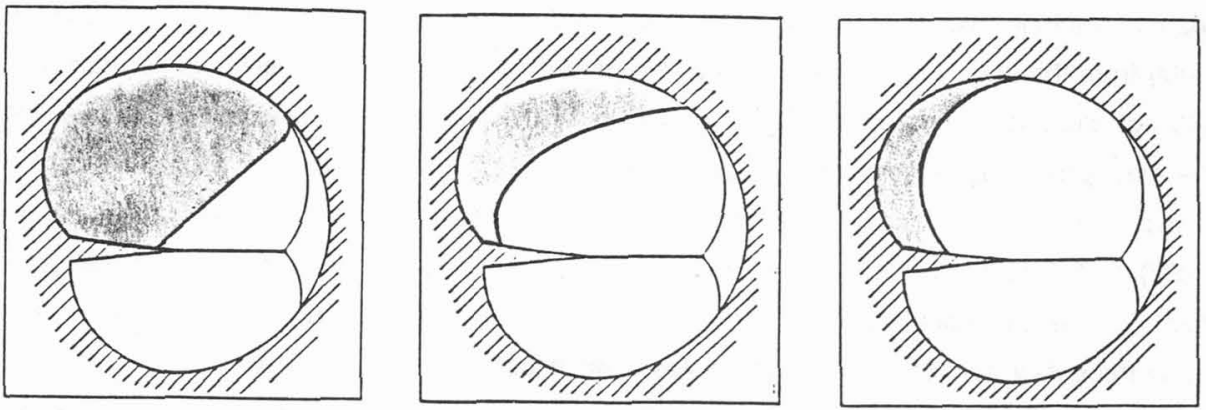

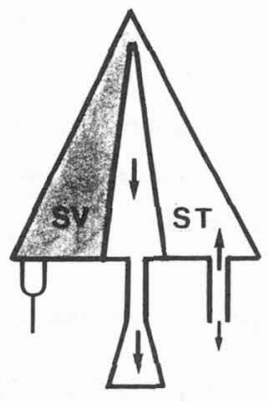

NORMAL

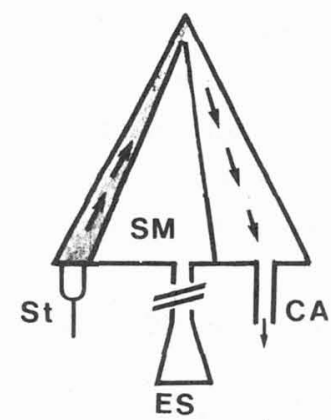

PHASE 1 HYDROPS

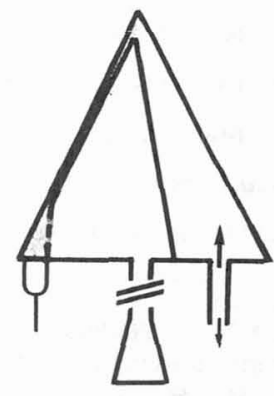

PHASE 2 HYDROPS

Figure 1. Schematic diagrams representing a transverse section through one cochlear turn (upper figures) and a longitudinal section through the cochlea (lower figures) at different stages in the development of endolymphatic hydrops. In the normal state the $\mathrm{K}+$ concentration of the two perilymphs are at different concentrations [scala vestibuli (SV) (shaded area) is $6.7 \mathrm{mM}$ whilst that of the scala tympani (ST) is $3.4 \mathrm{mM}$ ] - although the two perilymphs come physically together at the helicotrema at the apex of the cochlea. In phase 1 endolymphatic hydrops (when for example the absorption of endolymph is limited by blocking off the duct) the volume of endolymph swells, Reissner's membrane bulges out into the SV hence reducing the volume available for the perilymph within, and the SV perilymph is hence forced to flow into the ST via the helicotrema. At this stage a net escape of excess perilymph could occur via the cochlear aqueduct (CA) and intracochlear pressure changes would not be detectable although the relative doubling of the concentration of $\mathrm{K}+$ in the ST perilymph would in the long-term cause apical hair cell and spiral ganglion cell damage. However in a later phase 2, when Reissner's membrane approaches the wall of the cochlea and the volume of SV is completely obstructed an inner ear conductive loss would result giving rise to a feeling of fullness of the ear. Further secretion of endolymph in the absence of absorption might result in a considerable intracochlear pressure 